\title{
Awareness of parents about characteristics and carrying habits of backpack and its comparison with behavioral practices of their children
}

\author{
Patil MA ${ }^{1}$, Sumana $S^{2}$, Shagale $\mathbf{N}^{3}$ \\ ${ }^{1}$ Dr. Mohan A. Patil, Professor of Pediatrics, ${ }^{2}$ Dr. Sumana S, Senior Post Graduate Student, ${ }^{3}$ Dr Nithin Shagale, Junior \\ Post Graduate Student. All are attached to D.Y. Patil Medical College Kolhapur, Maharashtra, India.
}

Address for Correspondence: amohanpatil@gmail.com

\begin{abstract}
Background: Use of heavy backpacks and their potential to cause musculoskeletal injuries has been a matter of concern. Spine is in critical stage of development between the age group of 11-14 years. Musculoskeletal injury at this stage may lead to long term consequences. Parental awareness and behavioral practices of their children regarding backpack related health issues has major role to play. Hence in this cross sectional study parental knowledge regarding safe characteristics of backpack and correct method of using backpack was assessed and compared with behavioral practices of their children. Methods: Randomly selected 250 normal healthy school children aged 11-14 years and using backpacks from Kolhapur city, Maharashtra, India was study population. 124 boys and 126 girls from 6 schools, situated in different parts of city, representative of various economic strata of society participated in the study. On unscheduled day backpacks of children were assessed for its physical characteristics. Backpack carrying habit of the children was assessed when they carried their backpacks in their usual fashion. A validated questionnaire was administered to parents of school children. Data received was recorded in MS Excel worksheet and analyzed. Results: Mean actual weight of backpack was found to be $7.05 \pm \mathrm{SD} 1.15 \mathrm{~kg}$ with range of 4.32 to $12.5 \mathrm{~kg}$. Mean relative weight of backpack i.e. actual weight of backpack as compared to weight of child was $16.00 \pm \mathrm{SD} 2.08 \mathrm{~kg}$ with range of 11 to $23 \mathrm{~kg}$, which is certainly more than recommended weight. Knowledge of parents regarding characteristics and carrying practices of backpack was satisfactory in $62-90 \%$ parents, however it poorly reflected in behavioral practices of their children in most of the parameters. Conclusions: Parents knowledge about characteristics and carrying habits of backpack is poorly reflected into actual behavioral practices.
\end{abstract}

Keywords: Backpack Characteristics, Carrying habits, Behavioral practices, Parental awareness.

\section{Introduction}

Practice of carrying weight over back has been prevalent since long back. Previously it had been used mainly by trackers and soldiers. Effect of heavy backpacks on spine, back and posture has been described in medical literature [1-6]. Use of backpacks in school going children is more obviously noticed in Indian children in last few decades. Children are always in growing phase till they complete their adolescent growth spurt. Especially an adolescent period of 11-14 yrs is supposed to be critical as it is a period of accelerated growth and development of skeletal and soft tissues. Hence use of heavy backpacks especially in this sensitive period of vertebral column growth, has been a matter of concern for their possible adverse effect on spine, musculoskeletal system, posture, and respiratory system. These problems may be a significant factor in the development of mobility problems during adulthood [1,2, 7-9]. Musculoskeletal symptoms in children related to back can be multi factorial in origin. Incorrect use of backpacks remains one of the important causes after ruling out obvious causes like trauma, congenital musculoskeletal problems, poor physical built up, lack

Manuscript received: $2^{\text {nd }}$ March 2016

Reviewed: $14^{\text {th }}$ March 2016

Author Corrected; $20^{\text {th }}$ March 2016

Accepted for Publication: $31^{\text {st }}$ March 2016 
of exercise, excessive use of computers and intense physical activity. Medical problems associated with use of backpacks may be due to variety of causes working either singly or in combination. These factors can be physical characteristics of backpack, relative weight of backpack, method of carrying it, duration of carrying it, co-existing musculoskeletal problems. Children are not aware about the side effects of incorrect backpack carriage. Also they are not informed enough about selection of safe backpack and carrying it correctly. Parents play a vital role in selection of backpack. They are also close observer of carrying habit of backpacks of their child. For any health problem child is more likely to open up with their parents than anybody else. Hence it is not only the knowledge and awareness of parents regarding safe backpack use but its implementation in practice is the key determinant in prevention of backpack related health issues.

Considering regional differences in education system, different type of schools, variations in educational level, understanding and awareness of parents, behavioral practices; it was considered necessary to develop regional data which will help to plan preventive strategies for backpack related health issues. There are many studies done on use of heavy backpacks and its musculoskeletal, postural adverse effects. However we found only few studies are available on parental awareness and behavioral practices. Such studies may help in designing interventional strategies. Hence this study was conducted.

\section{Material \& Methods}

Normal healthy school going children aged 11-14 years and using traditional school backpacks were randomly selected from 6 different schools from Kolhapur city, Maharashtra, India. Schools from different localities were selected so as to cover children from all socioeconomic strata. The study was conducted after obtaining consent from institutional ethical committee and the school principal, parents, and the children themselves. The study was conducted between June to August, 2015. 124 boys and 126 girls with average age 12.96 years participated in the study. Children with obvious causes like trauma, congenital musculoskeletal problems, neurological problem, poor physical built up, lack of exercise, excessive use of computers and intense physical sports activity were excluded. This study was carried out on unscheduled day to avoid bias. Backpacks of children were assessed for its physical characteristics. Children were asked to carry their backpacks in their usual fashion. Backpack carrying habit of the children was observed. A validated questionnaire with language choice of either English or local language was administered to parents of school children. Knowledge of parents about school backpack was grouped in two domains, characteristics of standard school backpack and correct carrying method of school backpack. Five parameters were assessed for characteristics of backpack and ten parameters were assessed for carrying habit of backpack. 250 parents returned duly completed questionnaire. Data received was recorded in MS Excel worksheet and analyzed. Responses for all parameters were ' $y e s$, no or 'I don't know" choices; "yes" answers received a score of 1 and "no" or "I don't know" were scored 0. Higher scores on the scales indicated a greater knowledge. Test used for comparing two category variables is $\mathrm{Z}$ test for proportion. All quantitative variables are described by mean $\pm \mathrm{SD}$. Probability $\mathrm{P}<0.05$ is considered to be statistically significant at $5 \%$ level of significance and $\mathrm{P}<0.01$ is considered to be statistically highly significant at $1 \%$ level of significance.

\section{Results}

Total of 250 students were included in study with almost equal sex distribution of 124 boys and 126 girls (49.6\%M: $50.4 \% \mathrm{~F})$. Mean age of study population was $12.96 \mathrm{yrs} \pm \mathrm{SD} 0.94$. Mean actual weight of backpack was found to be 7.05 $\pm \mathrm{SD} 1.15 \mathrm{~kg}$ with range of 4.32 to $12.5 \mathrm{~kg}$. Mean relative weight of backpack i.e. actual weight of backpack as compared to weight of child was $16.00 \pm \mathrm{SD} 2.08 \mathrm{~kg}$ with range 11 to $23 \mathrm{~kg}$, which is certainly more than recommended relative weight of $10-15 \%$ in many studies. [4,7,8,17,18].(Table 1,2).

Table 1: distribution of children

\begin{tabular}{|l|l|l|}
\hline Sex & Number & Percentage \\
\hline Male & 124 & $49.6 \%$ \\
\hline Female & 126 & $50.4 \%$ \\
\hline Total & $\mathbf{2 5 0}$ & $\mathbf{1 0 0 \%}$ \\
\hline
\end{tabular}


Table 2: Mean and Range of Variables

\begin{tabular}{|l|l|l|}
\hline Variable & Mean \pm SD & Range \\
\hline Age & $12.96 \pm 0.94 \mathrm{yrs}$ & $11-15 \mathrm{yrs}$ \\
\hline Actual weight of children & $44.36 \pm 8.14 \mathrm{~kg}$ & $31-68 \mathrm{~kg}$ \\
\hline Actual weight of backpack & $7.05 \pm 1.15 \mathrm{~kg}$ & $4.32-12.5 \mathrm{~kg}$ \\
\hline Relative weight of the backpack & $16.00 \pm 2.08 \mathrm{~kg}$ & $11-23 \mathrm{~kg}$ \\
\hline
\end{tabular}

Knowledge of parents regarding characteristics of backpack showed that their knowledge regarding necessity of wide shoulder straps, padded shoulder straps, padding of rear of backpack and need for different parts in backpack for distribution of weight was satisfactory (81-94\%). However only $31.2 \%$ parents had knowledge regarding need of waist strap.

Analysis of knowledge of parents regarding carrying habit of backpack showed, balancing of weight of backpack, lifting with knee bent, use of both shoulder straps, placing it in the middle of back, not to carry it on one shoulder, weight of backpack less than $10 \%$ of body weight, positioning not above shoulder top and below waist was known to two third of parents $(62-82 \%)$. However correct method of wearing at waist level after putting it on table and fastening shoulder straps was known to only one third of parents $(32 \%)$.

Then actual behavioral practices of students were recorded. Data was analyzed to know whether knowledge of their parents was reflected in the practice. Parameters related to characteristics of backpack like use of backpack with wide, padded shoulder straps and padded rear of backpack and of waist straps showed statistically highly significant disparity between parental awareness and behavioral practices with $\mathrm{P}$ value $<0.01$.

However positive behavioral practices were noticed regarding use of backpacks with different parts for distribution of weight (Table3).

Table 3: Comparison of parental awareness and parental behavior about characteristics of backpack.

\begin{tabular}{|c|c|c|c|c|c|}
\hline $\begin{array}{l}\text { Sr. } \\
\text { No }\end{array}$ & Question & $\begin{array}{l}\text { \% of parents } \\
\text { with } \\
\text { knowledge } \\
\text { score } 1\end{array}$ & $\begin{array}{l}\text { \% of parents } \\
\text { with behavior } \\
\text { score } 1\end{array}$ & Z score & $\begin{array}{l}\text { P value } \\
\text { ( } P \leq 0.01 * * \\
\text { Highly } \\
\text { Significant) }\end{array}$ \\
\hline 1 & $\begin{array}{l}\text { Backpack with padded shoulder } \\
\text { straps }\end{array}$ & 87.2 & 6.8 & 18.01 & $\mathrm{P}<0.01 * *$ \\
\hline 2 & Backpack with wide shoulder straps & 94 & 21.05 & 21.05 & $\mathrm{P}<0.01 * *$ \\
\hline 3 & Backpack with waist strap & 31.2 & 7.09 & 7.09 & $\mathrm{P}<0.01 * *$ \\
\hline 4 & $\begin{array}{l}\text { Backpacks with different parts for } \\
\text { distribution of weight }\end{array}$ & 81.6 & 93.2 & 3.90 & $\mathrm{P}<0.01^{* *}$ \\
\hline 5 & $\begin{array}{l}\text { Padding at the rear of the backpack } \\
\text { where comes into contact with the } \\
\text { back and shoulders. }\end{array}$ & 88 & 6.4 & 18.27 & $\mathrm{P}<0.01 * *$ \\
\hline
\end{tabular}

Parental awareness and behavioral practices regarding parameters of carrying habits of backpack like balancing the weight of backpack in different parts of the backpack, lifting it with bent knees, wearing it after putting it on table at waist level, fastening shoulder strap firmly, positioning it at bottom of backpack not below the waist, not to carry it on 
one shoulder and keeping its weight less than $10 \%$ of body weight were showing disparity between knowledge and practice which was statistically highly significant with $\mathrm{P}$ value $<0.01$. However parameters like using both shoulder straps to prevent spine damage and positioning it over middle of back with top of the backpack not above the shoulders showed positive practices.(Table 4)

Table 4: Comparison of parental awareness and parental behavior about carrying habit of backpack.

\begin{tabular}{|c|c|c|c|c|c|}
\hline $\begin{array}{l}\text { Sr. } \\
\text { No }\end{array}$ & Question & $\begin{array}{l}\text { Knowledge of } \\
\text { backpack } \\
\text { carrying habit(\% } \\
\text { of parents who } \\
\text { answered yes) }\end{array}$ & $\begin{array}{l}\text { Behavior of } \\
\text { backpack } \\
\text { carrying habit ( } \\
\% \text { of parents } \\
\text { who behaved } \\
\text { yes) }\end{array}$ & $Z$ value & $\begin{array}{l}\text { P value } \\
(\mathbf{P} \leq 0.01 * * \\
\text { Highly } \\
\text { Significant) }\end{array}$ \\
\hline 1 & $\begin{array}{l}\text { Balancing the weight of backpack in } \\
\text { different parts of the backpack }\end{array}$ & 82.4 & 6 & 17.19 & $\mathrm{P}<0.01 * *$ \\
\hline 2 & $\begin{array}{l}\text { To lift the backpack it is better to } \\
\text { bend their knees, then take it }\end{array}$ & 76 & 0 & 17.50 & $\mathrm{P}<0.01 * *$ \\
\hline 3 & $\begin{array}{l}\text { Wear a backpack after putting it on a } \\
\text { table, at waist level }\end{array}$ & 32 & 0 & 9.75 & $\mathrm{P}<0.01 * *$ \\
\hline 4 & $\begin{array}{l}\text { The shoulder strap should be firm and } \\
\text { sufficiently fastened. }\end{array}$ & 32 & 0 & 9.75 & $\mathrm{P}<0.01 * *$ \\
\hline 5 & $\begin{array}{l}\text { Use both shoulder straps on the } \\
\text { backpack to prevent damage to the } \\
\text { spine }\end{array}$ & 75.6 & 44 & 7.20 & $\mathrm{P}<0.01 * *$ \\
\hline 6 & $\begin{array}{l}\text { Backpack is better be placed in the } \\
\text { middle of the back }\end{array}$ & 63.6 & 56 & 1.73 & $\begin{array}{l}\text { P } 0.08 \text { (Not } \\
\text { Significant) }\end{array}$ \\
\hline 7 & $\begin{array}{l}\text { Filled backpack should not weigh } \\
\text { more than } 10 \text { percent of body weight }\end{array}$ & 67.6 & 12.4 & 12.59 & $\mathrm{P}<0.01 * *$ \\
\hline 8 & $\begin{array}{l}\text { Backpack should not be above the top } \\
\text { of the shoulders }\end{array}$ & 62.4 & 75.2 & 3.08 & $\mathrm{P}-<0.01 * *$ \\
\hline 9 & $\begin{array}{l}\text { Bottom of a backpack should not be } \\
\text { lower than the waist }\end{array}$ & 63.6 & 0 & 15.26 & $\mathrm{P}-<0.01 * *$ \\
\hline 10 & $\begin{array}{l}\text { Don't Carry backpack on one } \\
\text { shoulder }\end{array}$ & 76 & 0 & 17.50 & $\mathrm{P}-<0.01 * *$ \\
\hline
\end{tabular}

\section{Discussion}

Use of backpacks by school going children has become popular in Indian children also. They pass through phases of physical growth throughout their childhood at varying pace. When child uses backpack, some compensatory postural changes occur $[5,6]$. Depending upon effect of variables like physical characteristics of backpack, relative weight of backpack, method of carrying it, duration of carrying it, co-existing musculoskeletal problems; child is prone to get musculoskeletal problems [9]. Adolescent spine is in sensitive phase of development [4,5]. Hence selection of backpack with safe physical characteristics and carrying it in relatively safer way will certainly contribute to prevent musculoskeletal problems in children. Parents have major role in selection of backpack. Similarly they are the close observer of carrying habit of backpack. Their knowledge about these issues related to backpack and its implementation in practice will certainly have a major role in safe use of backpacks.

Criteria for safe characteristics of backpack and its carrying practice have been decided in many studies. Wrong choice and wrong use of backpack can lead to various health issues. Backpacks should have wide, padded shoulder straps. Narrow straps dig painfully into shoulders and can hinder circulation, causing numbness or tingling in the arms, which over time may cause weakness in the hands. Padded shoulder straps help to absorb the load. Backpacks should have a waist or chest strap. This will help to keep the load close to the body 
and help maintain proper balance. Backpacks should also have a built in back and lumbar support. It should not weigh more than $10 \%$ of one's body weight. Recommendations for backpack use are wear both shoulder straps. Slinging a backpack over one shoulder causes a person to lean to one side to compensate for the uneven weight, curving the spine. Over time, this can cause lower and upper back pain, strained shoulders and neck, and even functional scoliosis, or curvature of the spine. Teenage girls are especially susceptible to scoliosis. Distribute weight evenly across your back. The more spread out a load is, the less strain it puts on any one part of your body. Load pack so the heaviest items are right next to your back. Snug shoulder straps so the pack fits close to the upper part of your back. The further a backpack's load is from your back, the more it pulls you backward and strains muscles between your shoulders. We should use the waist belt, and side/chest straps. Keep the load close to your body. Keeping the pack close to your hips also shifts "work" to your legs. The bottom should rest in the curve of your lower back and the top touch just below the vertebral prominence on your neck. Neatly pack your backpack, and try to keep items evenly distributed with heavier items kept in the bottom.[5,8,10,12,16]. Carrying backpacks on posterior aspect of the body causes shift of child's center of gravity. It leads to postural compensation of spine by bending forward. These alterations may cause back pain and injury by stressing the ligaments or muscles in the back or by changing the forces applied to intervertebral discs [1,5]. Similarly such postural deviations can hamper the natural shock absorption abilities of the spine and require greater muscle activity to prevent the individual from falling as a result of the increased forces and moments about the spine. These heavy school bags result in several postural changes at the head and trunk placing soft tissues at a biomechanical disadvantage resulting in fatigue and injury. This can result in repetitive stress injuries to the growing spine. Backpack loads exceeding $10 \%$ of body weight have been shown to increase energy consumption, increase trunk forward lean, and result in decreased lung volumes. These factors lead to reduced oxygen partial pressure (PO2) resulting in anaerobic respiration and eventual fatigue. It also causes decrease in vital capacity $[4,5,15,19]$.

Our study showed knowledge of parents regarding characteristics of backpack in most of the assessed parameters was satisfactory (81-94\%) except need of

\section{Conclusion}

waist strap which was known to only $31.2 \%$ parents. Similarly knowledge of parents on carrying habit of backpack was adequate in most of the assessed parameters $(62-82 \%)$ in two third of parents. However correct method of wearing at waist level after putting it on table and fastening shoulder straps was known to only one third of parents (32\%).In a similar study in Iran, Zeinab Javadivala et al found 51 to $56 \%$ parents were aware of recommended weight limit and carrying habit of backpack. $89.1 \%$ parents were not aware of appropriate size of backpack [7]. Janakiraman Balamurugan in his study in Chennai city reported a mean schoolbag weight as a percentage of body weight, $16.31 \%$ in male and $16.22 \%$ in female elementary school children [4]. In a study conducted in India, Rageswarihariharan A. et al found that the mean bag weight carried by urban school children was $7.1 \mathrm{Kg}$ which is $17 \%$ of their body weight and for rural school children its $3.2 \mathrm{Kg}$, which is $12 \%$ of their body weight [20]. In a study in Amritsar Punjab, India, Koley and Kaur found backpack weight carried by the school children was between $7.48 \%-16.83 \%$ of their body weight. [1].These figures are comparable with findings in present study. In a similar study of parental awareness of standard school backpack Neama Mohamed El Magrabi et al found similar observations like our study. Parents were unaware about need for waist strap. However in parameters of carrying school backpacks correctly, parents were unaware of standard methods. [11]. Dianat I, Karimi MA in their study of 11-14 years students in Tabriz, Iran found low level of awareness amongst parents regarding recommended weight limit, appropriate method of carrying schoolbags, and schoolbag strap adjustments. [14]. Manisha Malik, Deepa Vinay in their study of parental awareness about school backpack done in Meerut city found similar findings, ranging $70-90 \%$ in various backpack parameters with poor reflection in behavioral practices.[13].

Most of the studies done in India and outside indicate unsatisfactory level of parental awareness regarding characteristics and carrying habits of backpacks. Also at existing levels of parental awareness these healthy practices are not getting reflected into behavior of the children. Selection of a safe and appropriate backpack is a family affair. It is combined responsibility of parents and children to realize the importance of proper selection of backpack and wearing it correctly so as to prevent backpack related health issues in adult life.

Parents play key role in selection of appropriate backpack, checking its weight, supervising carrying 
method. However there is wide gap exists between knowledge of parents regarding safe use of backpacks and actual practice by their children. There is need to bridge this gap with health education so as to prevent backpack related health issues.

generalized. It needs more studies from this region to confirm the findings. Similarly duration of carrying backpack was not taken into account due to feasibility problem.

Acknowledgement: We sincerely thank the children, parents and staff of all schools for their co-operation in

\section{References}

1. Shyamal Koley and Navneet Kaur. An Association of Backpack Weight and Postural Habits in School Going Children of Amritsar, Punjab, India. Anthropologist, 12(2): 107-111 (2010).

2. Rateau, Margaret R. Use of Backpacks in Children and Adolescents: A Potential Contributor of Back Pain. Orthopaedic Nursing: March/April 2004 - Volume 23 Issue 2 - pp 101-105.

3. Skaggs DL, Early SD, D'Ambra P, Tolo VT, Kay RM. Back pain and backpacks in school children. J Pediatr Orthop. 2006 May-Jun;26(3):358-63.

4. Janakiraman Balamurugan. School Bags and Musculoskeletal Pain Among Elementary School Children In Chennai City .International journal of medical science and clinical Invention. Volume 1 issue 62014 page no. 302-309.

5. Deepak Sharan, Ajeesh P S, Jerrish A Jose, Sukrit Debnath and Manjula M. Backpack injuries in Indian School children : risk factors and clinical presentations. Work 41(2012) 929-932.

6. Walicka-Cupryś K, Skalska-Izdebska R, Rachwał M, Truszczyńska A. Influence of the Weight of a School

Backpack on Spinal Curvature in the Sagittal Plane of Seven-Year-Old Children. Biomed Res Int. 2015;2015:817913.

7. Zeinab Javadivala, Hamid Allahverdipour, Iman Dianat, and Mohsen Bazargan A Awareness of Parents about Characteristics of a Healthy School Backpack. Health Promot Perspect. 2012; 2(2): 166-172. this study. We thank Mrs. M.M. Desai, Statistician for her help in statistical analysis.

Funding: None

Conflicts of Interest: None

Limitations- This study has few limitations. Sample size is small. Hence findings of this study may not be

8. G N Lucas. Backpacks in children. Editorial. Sri Lanka Journal of Child Health, 2011; Volume 40, Issue 1: $1-3$.

9. Rai A, Agarwal S, Bharti S. Postural Effect of Back Packs on School Children: Its Consequences on Their Body Posture. . IJHSR. 2013; 3(10): 109-116.

10. www.aota.org/backpack. The American Occupational Therapy Association Guidelines for selection and wearing of backpack.

11. Neama Mohamed El Magrabi, Safaa Rashad Mahmoud, and Yousrria El-Sayed Yousef. Awareness of parents about school backpack and its related musculoskeletal disorders in Assiut City . IOSR Journal of Nursing and Health Science (IOSR-JNHS) Volume 4, Issue 6 Ver. V (Nov. - Dec. 2015), 05-11.

12. Ruth Levy Guyer. Backpack=Back Pain. American Journal of Public Health January 2001, Vol. 91, No. 1:16-19.

13. Manisha Malik, Deepa Vinay Awareness Assessment of Parents and Teachers About School Backpack Paripex - Indian Journal Of Research, Vol: 4, Issue: 1 January 2015

14. Dianat I, Karimi MA. Association of parental awareness of using schoolbags with musculoskeletal symptoms and carrying habits of schoolchildren. J Sch Nurs. 2014 Dec;30(6):440-7.

15. Rai A, Agarwal S, Bharti S. Postural Effect of Back Packs on School Children: Its Consequences on Their Body Posture. IJHSR. 2013; 3(10): 109-116.

16. Avantika Rai, Shalini Agarawal. Back Problems Due To Heavy Backpacks in School Children .IOSR 
Journal Of Humanities And Social Science (IOSRJHSS) Volume 10, Issue 6 (May. - Jun. 2013), PP 22-26 17. Ramprasad M, Alias J, Raghuveer AK. Effect of Backpack Weight on Postural Angles in Preadolescent Children. Indian Pediatr. 2010 (Jul 7); 47 (7): 575-580.

18. Moore MJ, White GL, Moore DL. Association of Relative Backpack Weight With Reported Pain, Pain Sites, Medical Utilization, and Lost School Time in Children and Adolescents. J Sch Health. 2007 (May); 77 (5): 232-239.
19. Amro, Amen al faqeeh. The effect of School Bag weight on Pain Posture and Vital capacity of lungs of Three Elementary School in Bethlehem District in Palestine.Middle East Journal of Family Medicine. August 2009; Volume 7,Issue 7: 7-14.

20. Rageswarihariharan ,A. Zechariah Jebakumar, K Madhumathi. Backpack- Bad Pack an Iisue, Backpack Uusage and its Implications on Indian School Children, an Observational Study on the Impact of Backpack Betwween Rural and Urban School Children. Physiotherapy and Occupational Therapy Journal, Volume 2009; 2(1): 5-11.

\section{How to cite this article?}

Patil MA, Sumana S, Shagale N, Awareness of parents about characteristics and carrying habits of backpack and its comparison with behavioral practices of their children. Int J Pediatr Res 2016;3(3):176-182. doi:10.17511/ijpr.2016.i03.07. 